\section{MP4-063 当院における膀胱癌の臨床的检討}

\section{国立病院機楎災鼋医療センター泌尿器科", 昭和大学医 学部泌尿器科学 ${ }^{2)}$}

石原 理裕 ${ }^{1}$, 大森 圭 ${ }^{1}$, 齊藤 克幸 ${ }^{11}$, 笠原 敏男 ${ }^{12}$,

檜垣 昌夫"), 船橋 健二郎 ${ }^{2}$, 吉田 英機2)

【目的】1994 年 1 月から 2003 年 12 月までの 10 年間に当 科で経験した 142 例の原発性膀胱癌について臨林的検討 を行った。対象】症例は男性 110 例、女性 32 例で、年齢 は 38 91 歳 (平均 66.5 歳)、観察期間は 1 129 ヶ月 (平 均 33.7 ケ月）であった。結果】初回治療では TUR-Bt が 90 例、 BCG 膀胱内注入が 2 例、膀胱部分切除術が 2 例、膀胱全摘除術が 48 例に施行された。全症例の 3 年生 存率は $78.1 \% 、 5$ 年生存率は $76.7 \%$ であった。樑達度別に は pTis: 5 例、pTa: 71 例、pT1:23例、pT2:13 例、pT $3: 24$ 例、 $\mathrm{pT} 4: 6$ 例であり、深達度別 5 年生存率は $\mathrm{pT}$ is : $75.0 \%$ 、pTa: $97.0 \%$, pT $1: 91.3 \%$, pT $2: 83.3 \%$, pT3: $37.5 \% 、 \mathrm{pT} 4: 0 \%$ であった。異型度別においては G1:30 例、G2: 73 例、G3:39 例であり、異型度別 5 年生存率は G1 : 96.4\%、G2: 84.2\%、G3:52.5\%であった。また、TUR -Bt が施行された患者の $1 、 3 、 5$ 年非再発率は $73.1 \%$ 、 $62.3 \% 、 58.7 \%$ であった。さらに検討を加え報告する。

\section{MP4-064 根治的勝胱全摔術を施行した胳缕癌患 者の予後解析}

\section{旭川医科大学医学部泌尿器科学}

佐賀 祐司, 安住 誠, 加藤 祐司, 德光 正行, 山口 聡, 橋本 博, 金子 茂男, 八竹 直

【目的】膀胱全摘術が施行された膀胱癌症例に関して、膀胱 癌取り扱い規約第 3 版に基づき臨床病理学的に検討した。 【方法】1987 年から 2004 年までに当科で根治的膀胱全摘術 が施行された膀胱腫韵症例 93 例を対象とした。男性 73 例、 女性 20 例、手術時平均年齢は 66 歳 (33 81 歳)、平均観察 期間は 58 か月（1 144 か月）であった。2001 年 11 月以前 の患者については、TNM 分類を膀胱癌取り扱い規約第 3 版に準じて変換し解析した。患者の生存率は Kaplan-Meier 法にて算出し、 logrank testにて解析した。結果】全症例の 疾患特異的生存率は 3 年 $78 \% 、 5$ 年 $68 \%$ であった。解析の 結果、異型度 G2 と G3 間で予後に差異を認めなかった。深 達度 $\mathrm{pT} 2 \mathrm{a}$ 群と $\mathrm{pT} 2 \mathrm{~b}$ 群では予後に差異を認めたものの、 $\mathrm{pT} 2 \mathrm{~b}$ 群と $\mathrm{pT} 3$ 群間では差異を認めなかった。他の病理学 的パラメーターの解析では組織学的浸潤增殖様式、壁内リ ンパ管侵襲、壁内静脈侵襲、所属リンパ節転移がそれぞれ子 後因子として関与していた。考察】膀胱全摘術を行なった 膀胱癌患者の予後解析を行なった結果、深達度、組織学的浸 潤增殖梯式、壁内リンパ管侵襲、壁内静脈侵襲、所属リンパ 節転移がそれぞれ子後因子として関与した。手術前後の補 助療法の有用性についても検討予定である。

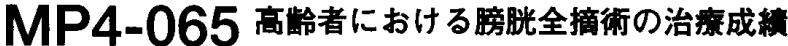

\section{京都大学医学部泌尿器科学}

西山 博之, 高橋 毅, 東 新, 伊藤 哲之, 山本 新吾, 賀本 敏行, 小川 修

【目的】本邦では高齢化社会を迎え、“高齢者における膀胱 癌に対する治療をどうするか？”が大きな臨床的問題と なりつつある。一般には、浸润性膀胱癌に対する標準的 治療は根治的膀胱全摘術であり、近年の麻醉管理、周術 期管理、手術法等の技術の向上により膀胱全摘術の周術 期死亡率は低下している。このような背景をもとに、今 回我々は 80 歳以上の膀胱全摘症例における治療成績に ついて検討した。方法】我々が既に報告した浸潤性膀胱 癌に対する多施設アウトカム研究(西山Eur.Urol.2004)に 登録されている症例を対象に治療方法と予後について比 較検討した。成續】登録症例 1131 例中、80 歳以上の症例 は 62 例 $(5.5 \%)$ であった。 80 歳以上の症例では比較的女 性が多い傾向があった。リンパ節廊清を施行された症例 は $59 \%$ 、補助化学療法併用症例は $6.5 \%$ と 80 歳未満の症 例に比し低かった。周術期死亡例はなく、 3 年全生存率で は pT2b 以下では 80 歳以上の症例は予後不良であった が、 pT3 以上の症例群では 80 歳以上と 80 歳未満では明 らかな差は認められなかった (64.2\%。v vs 66.7\%)。【結論】 今回の検討により、80 歳以上の症例に対しても、症例を 選択すれば膀胱全摘術により若年者と同様の予後が期待 されると考えられた。

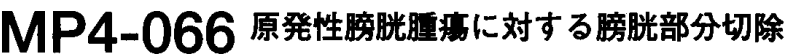 術の予後検討}

\section{佐賀大学医学部泌尿器科}

西村 和重,柿木 寛明,有働 和馬,金子 新, 佐藤 勇司, 中島 のぶよ,中島 敬二, 德田 雄治, 魚住 二郎, 真崎 善二郎

[目的] 原発性膀胱腫湟に対する膀胱部分切除術が根治性 という観点から膀胱全摘除術と比してどうであるか否か を検討するため膀胱部分切除術の予後を膀胱全摘除術と 比較した。[対象と方法] 当科で行った 1996 年以降の膀胱 部分切除術 24 例（T1:7 例、 $\mathrm{T} 2: 7$ 例、 $\mathrm{T} 3$ 以上: 10 例） と同時期に行った膀胱全摘除術 25 例（T1: 4 例、 $\mathrm{T} 2: 10$ 例、 T3 以上：11 例)を対象とした。病期診断は内視鏡下 生検と CT あるいは MRIにより行った。全症例の内 30 名に術前補助療法 (化学療法単独 17 例、放射線併用化学 療法 13 例）を行った。[結果] 観察期間の中央値は膀胱部 分切除症例で 24.5 力月、膀胱全摘除症例で 64 力月で あった。癌無生存、癌有生存、癌死、局所再発、遠隔転 移は膀胱部分切除症例でそれぞれ 17 例、0 例、6 例、6 例、 5 例、膀胱全摘除症例でそれぞれ 16 例、 5 例、4 例、 4 例、7 例であった。[結論]膀胱部分切除術は根治性にお いて膀胱全摘除術に劣るとされるが、今回の検討におい て、予後は膀胱全摘除術とほほ同等と思われた。 